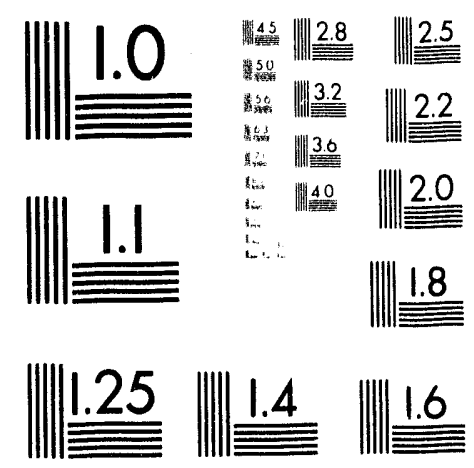



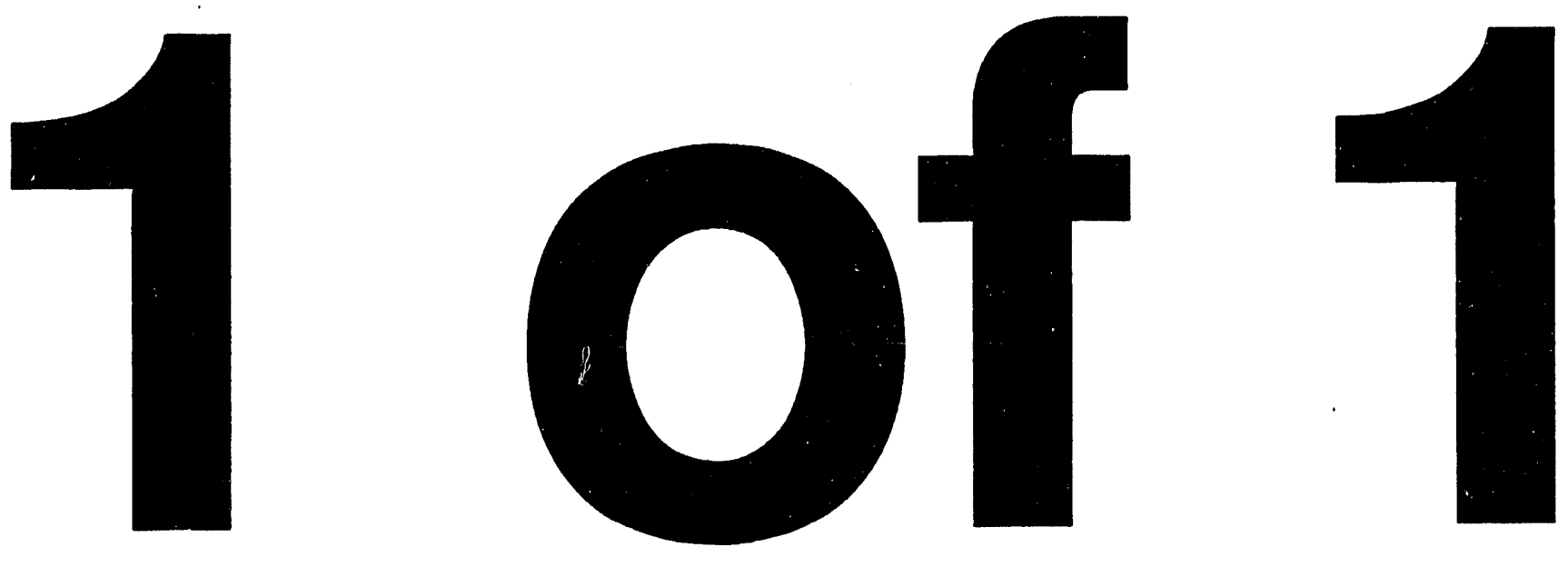


\section{An Economic Feasibility Analysis of Distributed Electric Power Generation Based Upon the Natural Gas-Fired Fuel Cell A Model of a Central Utility Plant}

\section{Topical Report}

Staff,

Manes Associates, Incorporated

June 30, 1993

Work Performed Under Cooperative Agreement No.: DE-FC21-92MC29227

For

U.S. Department of Energy

Office of Fossil Energy

Morgantown Energy Technology Center

Morgantown, West Virginia

By

Southern Califomia Gas Company

Los Angeles, California 


\section{DISCLAIMER}

This report was prepared as an account of work sponsored by an agency of the United States Government. Neither the United States Government nor any agency thereof, nor any of their employees, makes any warranty, express or implied, or assumes any legal liability or responsibility for the accuracy, completeness, or usefulness of any information, apparatus, product, or process disclosed, or represents that its use would not infringe privately owned rights. Reference herein to any specific commercial product, process, or service by trade name, trademark, manufacturer, or otherwise does not necessarily constitute or imply its endorsement, recommendation, or favoring by the United States Government or any agency thereof. The views and opinions of authors expressed herein do not necessarily state or reflect those of the United States Government or any agency thereof.

This report has been reproduced directly from the best available copy.

Available to DOE and DOE contractors from the Office of Scientific and Technical Information, P.O. Box 62, Oak Ridge, TN 37831; prices available at (615) 576-8401.

Available to the public from the National Technical Information Service, U.S. Department of Commerce, 5285 Port Royal Rd., Springfield, VA 22161; phone orders accepted at (703) 487-4650. 


\title{
An Economic Feasibility Analysis of Distributed Electric Power Generation Based Upon the Natural Gas-Fired Fuel Cell A Model of a Central Utility Plant
}

\section{Topical Report}

\author{
Staff, \\ Manes Associates, Incorporated
}

Work Performed Under Cooperative Agreement No.: DE-FC21-92MC29227

\author{
For \\ U.S. Department of Energy \\ Office of Fossil Energy \\ Morgantown Energy Technology Center \\ P.O. Box 880 \\ Morgantown, West Virginia 26507-0880 \\ Southern California Gas Company \\ 555 W. Fifth Street \\ Los Angeles, California 90013-1011
}

June 30, 1993 


\section{ABSTRACT}

"A Model of a Central Utilities Plant Based upon a Natural Gas-Fired Fuel Cell" is the fourth topical report of the program for an "Economic Feasibility Analysis of Distributed Electric Power Generation Based Upon the Natural Gas-Fired Fuel Cell." This central utilities plant model details the major elements of a central utilities plant for several classes of users. The model enables the analyst to select optional, cost effective, plant features that are appropriate to a fuel cell application. These features permit the future plant owner to exploit all of the energy produced by the fuel cell, thereby reducing the total cost of ownership. The model further affords the analyst an opportunity to identify avoided costs of the fuel cell-based power plant.

This definition establishes the performance and capacity information, appropriate to the class of user, to support the capital cost model and the feasibility analysis. It is not intended to advance the state-of-the art in the design of heating and ventilation central plant systems, rather it is detailed only to the depth required to identify the major elements of a fuel cell-based system.

The model permits the choice of system features that would be suitable for a large condominium complex or a residential institution such as a hotel, boarding school or prison. The user may also select large office buildings that are characterized by 12 to 16 hours per day of operation or industrial users with a steady demand for thermal and electrical energy around the clock. Other applications that have still higher relative demand for thermal energy are also well-suited to fuel cell application because of the fuel cell's "free" source of hot water or steam. Hov'ever, those applications need not be modeled to demonstrate the economic advantage of the fuel cell.

Keywords: Fuel Cell, Economic Analysis, Thermal Energy Distribution, Distributed Power Generation, Feasibility Analysis, Central Plant Configuration 


\section{FOREWORD}

This report was prepared under cooperative agreement No. DE-FC21-92MC29227, among the US Department of Energy, Fossil Energy, Morgantown Energy Technology Center, The Southern California Gas Company, The Brooklyn Union Gas Company and the Manes Associates, Incorporated. The participants are sponsoring an investigation by the Manes Associates, of the "Economic Feasibility of Distributed Electric Power Generation Based Upon the Natural Gas-Fired Fuel Cell."

This report, A Central Utilities Plant System Definition for a Natural Gas-Fired Fuel Cell is the fourth deliverable report of the contract. It is submitted in accord with Attachment $B$, Paragraph $B$ of the "Financial Assistance Reporting Requirements Checklist." 


\section{TABLE OF CONTENTS}

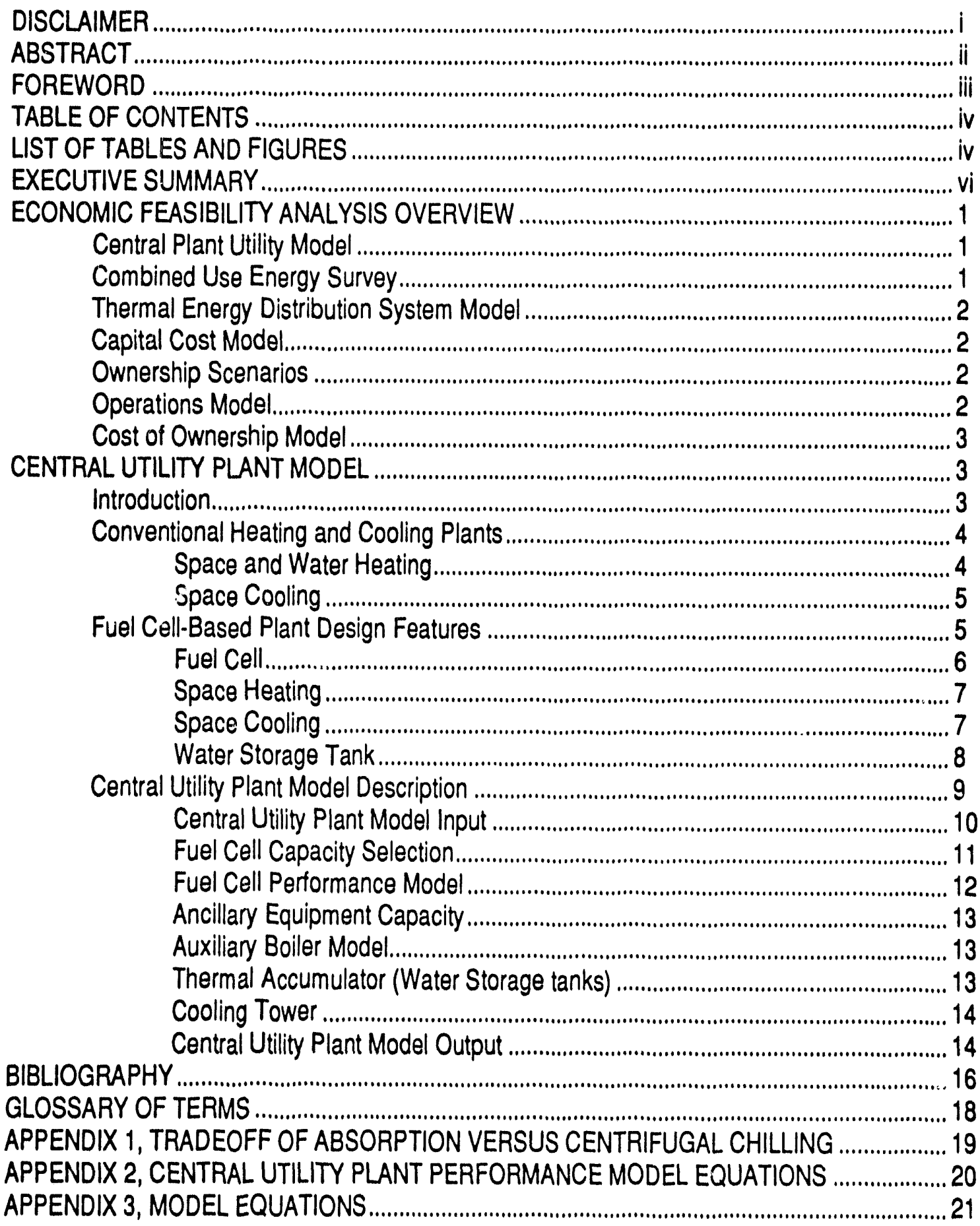




\section{LIST OF TABLES AND FIGURES}

Table No. 1, Comparison of Absorption and Centrifugal Chillers .................................. 7

Table No. 2, Central Utility Plant Model input Sheet......................................................... 10

Table No. 3, Central Utility Plant Model Output................................................................ 14

Table No. 4, Central Utility Plant. Model Constants ...................................................... 15

Figure No. 1, Elements of An Economic Feasibility Analysis of Fuel Cell-Based Power

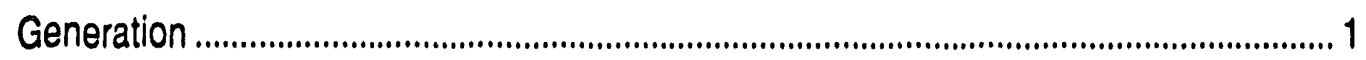

Figure No. 2, Conventional Central Utility Plant.......................................................... 5

Figure No. 3, Fuel Cell-Based Central Utility Plant ........................................................ 6

Figure No. 4, Central Utility Plant Model ..................................................................... 9

Figure No. 5, Idealized Class I User Demand Curve..................................................... 11

Figure No. 6, Fuel Cell performance Model ............................................................... 13 


\section{EXECUTIVE SUMMARY}

The natural gas fired-fuel cell produces electrical and thermal energy in an electrochemical reaction between natural gas fuel and oxygen from the air. The currently available phosphoric acid electrolyte cell produces about half of its energy in the form of hot $\left(\sim 175^{\circ} \mathrm{F}\right)$ water. Newer technologies, such as molten carbonate or solid oxide produce even higher potential thermal energy in the form of high pressure steam.

The electrical energy conversion efficiency of the fuel cell is $44 \%$. The overall energy conversion efficiency is over $80 \%$ If the thermal energy produced is included. Higher system efficiency will result in low cost electrical power in most applications. Developing the central utility plant model has suggested several characteristics of fuel cell-based plant design that enable the potential owner to capture the economic benefits of the higher efficiency energy conversion.

- Fuel cell-based central utility plant systems, sized to meet the peak electrical demand of an application with duty cycles as low as $75 \%$, can have a lower cost of ownership than a purchased power alternate.

- The variation in an application's demand for thermal energy is readily manageable. Excess thermal energy produced during off-peak hours and be saved and used to meet peak consumption demands. Thermal energy production considerations should not drive fuel cell sizing considerations.

- The economic benefits, of $80 \%$ efficient energy conversion can be captured by considering the fuel cell as an element in a larger plant system that includes combined applications demand matching, thermal energy demand averaging and appliance load switching from electricity to thermal energy.

Potential applications that use or plan to use a hydronic system for space conditioning are most likely to fully utilize the energy conversion capacity of the fuel cell. This system will make the best use of all of the energy produced and ensure uninterrupted service in the event of unscheduled fuel cell-based central plant down time include a four-pipe hydronic thermal energy distribution system.

A second important use of the thermal energy from the fuel cell is air-conditioning that utilizes an absorption chiller in association with the hydronic distribution system. The economy-of-scale of larger absorption systems, combined with their lower operating costs, can make absorption chilling the most economical space conditioning system and improve the economics of the fuel cell.

The central plant model;

- matches the design capacity of the fuel cell to the application(s) demand,

- Identifies and sizes central plant features to effectively utilize the energy produced,

- estimates the capacity of central plant elements as input to the capital cost model, and

- computes natural gas consumption and thermal energy produced as a function of fuel cell electrical load as input to the operations model. 


\section{ECONOMIC FEASIBILITY ANALYSIS OVERVIEW}

This report is a description of the "Central Utility Plant Model" that is an important element of the cost of ownership model being developed for the project for "An Economic Feasibility Analysis of "Distributed Electric Power Generation Based upon the Natural Gas.Fired Fuel Cell" The project is further comprised of a comprised of a survey of energy users, and numeric models of an energy distribution system, capital cost of the hardware elements and an operations model. The models' output is combined with a series of ownership scenarios to drive a model of the cost of ownership of a fuel cell-based power generation system. Figure No. 1 is a diagram of the relationship among the project elements.

Figure No. 1, Elements of An Economic Feasibility Analysis of Fuel Cell-Based Power Generation

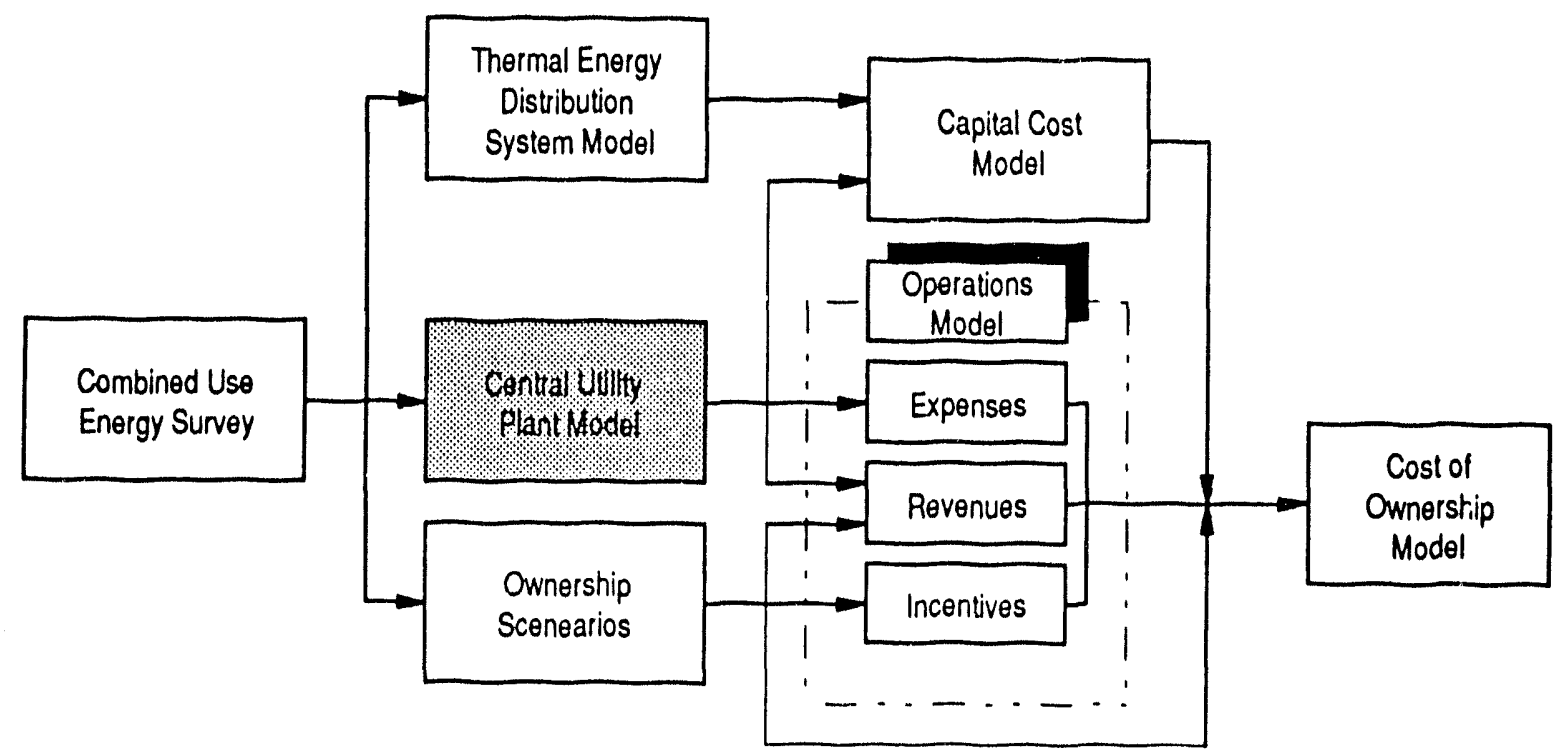

\section{Central Plant Utility Model}

This report describes the central plant utility model and its relationship to the other elements of the project. The relationship is further illustrated by shading the appropriate portion of Figure No. 1. The central plant model sizes a fuel cell for one of several user-chosen electrical demand profiles. The thermal energy produced is a dependent variable of the electric energy computed by a model of fuel cell performance and gas consumption. The model computes the thermal energy required for space conditioning and other uses to size an absorption chiller, boiler, thermal accumulator tank and system pumps.

\section{Combined Use Energy Survey}

A survey of the extensive literature on energy consumption among a variety of user classes was conducted to establish the consumption rates and the relationship between consumption of thermal and electrical energy. The literature survey was supplemented with data on consumption history contributed by 15 industrial energy users in the Southern California area. The data fell into categories of demand profiles by industry and end-use that were non-dimensionalized by peak use. The profiles were used to model the 
fuel cell-based utility plant that could satisfy the demand and a distribution system to deliver the thermal energy to the point of use. The survey report is complete and was submitted under separate cover.

\section{Thermal Energy Distribution System Model}

The report describes several types of ther.inal energy distribution systems that are suitable for the distribution of thermal energy to multiple points of use. The primary conclusion drawn from the work is that a four-pipe, hydronic distribution system is most suitable for adaptation of the fuel cell based central plant. The report on the model is complete and was submitted under separate cover.

\section{Capital Cost Model}

The model computes the capital cost of the ancillary elements of the central utility plant by scaling cost data from the R. S. Means Co.'s "Means Mechanical Cost Data, 1992" with a series of scaling relationships developed by multiple linear regression. The capacity or size of each element of the utility plant varies as a dependent variable of demand profile and user specified space conditioning loads. The capital cost of the fuel cell is varies with a manufacturing learning expression. The initial value of fuel cell cost ( the staring point on the learning curve) is one of the parameters of the feasibility analysis.

\section{Ownership Scenarios}

The treatment of revenues, expenses and incentives are dependent on the owners contractual and regulatory status with respect to the utility companies in the service area and the owner's customers for the energy produced by the fuel cell. The capital recovery period and the requisite return on investment will also vary by the class of owner, their industry and regulation.

\section{Operations Model}

The business operations model computes fuel cell operating expenses based upon gas price forecasts or an input parameter. The maintenance expenses include periodic fuel cell stack refurbishment and the purchase of back-up electric power and additional space heating boiler fuel while the cell is out of service.

The revenue stream is imputed from the avoided cost of purchasing electric and thermal energy at rates appropriate to the ownership class, time of clay and season. The power and thermal energy production rates are computed by the Central Utility Plant Model. An additionai revenue stream is derived from investment credit, utility displacement credits or RECLAIM' permit sales. In some cases the enabling legislation to support these incentives does not yet exist. Provisions have been included in the operations model to enable the prospective owner to account for this important source of revenue and public good-will.

\footnotetext{
${ }_{1}^{1}$ RECLAIM is the recently announced program of the South Coast Air Quality Management District to create a trading market for emission permits. The emissions of a fuel cell is below the most stringent limits proposed for the year 2010. A fuel cell owner should be able to sell all of their annual permit allowances on the open market. Similar programs have aiready been established at the federal level and will likely be emulated in other non-compliant areas of the country.
} 


\section{Cost of Ownership Model}

A model of the cost of fuel cell ownership is the final product of the series of models represented in Figure No. 1. The model combines the product of the capital cost model, ownership scenarios and the operations model cash flows to compute the cost of ownership. The form of the output is user selectable from a menu that includes cash flow curves, net present value as a function of capital cost and fuel cost or the internal rate of return on investment.

\section{CENTRAL UTILITY PLANT MODEL}

\section{Introduction}

The term "central utility plant" refers to the centrally located equipment of a building or set of buildings whose functions are to supply or distribute the following: (a) electrical energy; (b) domestic hot water; (c) space heating; (d) air-conditioning; and (e) process heat. Since the fuel cell can supply some or all of the energy for these functions, it is considered part of the central plant.

This first sections of this report describe the function of elements of a conventional, combustion energypowered utility plant and compares it with a similar utility plant that uses a fuel cell. The following sections describe the numerical model of the central utility plant and how it is used in the "Economic Feasibility Analysis of Distributed Electric Power Generation Based upon the Natural Gas-Fired Fuel Cell."

A plausible scenario for an analysis of the cost-of ownership of a fuel cell need not consider the costs of central utility plant elements other than the fuel cell. A large energy consumer's modern utility plant will normally include many of the elements that a fuel cell based plant will include. In such cases the analysis of fuel cell cost-of-ownership should consider the fuel cell as an incremental capital cost. Other elements would not be included in the analysis.

This analysis includes the elements of the central utility plant to account for additions or changes in equipment capacity that enable the future owner to productively use the thermal energy produced by the fuel cell, thereby reducing the cost-of-ownership. The present value of electricity produced by a $200 \mathrm{~kW}$ fuel cell is about \$2.4. million² at present Southern California energy prices. The value of the thermal energy produced adds another $\$ 300,000^{3}$ without increased operating costs.

The cost-effective application of fuel cell technoiogy may require some additions to the typical, central plant for heating and cooling. Most central plants are designed to utilize thermal energy from fuel combustion and electricity from a Utility Electric Generator. Some modifications are necessary to utilize the thermal energy produced by the fuel cell in the form of hot water. In other applications it may be possible to avoid certain capital costs as the result of fuel cell application. This report describes a model of central utility

\footnotetext{
${ }^{2}$ The present value of $200 \mathrm{~kW}$ at $0.1185 \$ / \mathrm{kWhr}$ over 20 years at a discount rate of $6 \%$ is $\$ 2.4$ million.

${ }^{3}$ One commercially available, $200 \mathrm{~kW}$ fuel cell produces $850,000 \mathrm{Btu} / \mathrm{hr}$. in the form of hol $\left(\sim 175^{\circ} \mathrm{F}\right)$ water. The cost of producing the equivalent energy includes the amortized cost of a boiler and its natural gas fuel. Newer technologies are expected to produce higher potential thermal energy in about the same proportions.
} 
plant designs that use fuel cells and those that are based on conventional heating and ventilation ( $\mathrm{H} \& \mathrm{~V}$ ) design. The purpose of the central utility plant model is to establish the technical characteristics of a central utility plant that are appropriate to a particular class of prospective fuel cell owner. It further serves as input to the capital and operations cost models required to compute the cost of fuel cell ownership. The central utility plant model:

- matches the user's energy demand with an optimum capacity fuel cell as a function of operating policy and periodic variations in electrical and thermal demand,

- includes an "elastic" model of the fuel cell to forecast the performance of the preser" anddeveloping technology,

- computes the electrical, thermal, flow and volumetric capacity of elements as input to the capital and operations cost models.

\section{Conventional Heating and Cooling Plants}

The conventional4 central utility plant design adopted for this analysis is a system that uses combustion energy to supply space and water heating. It provides chilled water for space cooling from an electrically powered centrifugal chiller and distributes the electrical energy supplied by the local utility. The plant is termed "conventional" in that it does not include a fuel cell for primary energy conversion. The features chosen are characteristic of a large, modern utility plant. The configuration was defined to identify plant features that may be affected by the addition of a fuel cell, not as an exercise in the design of an optimum heating and ventilation system design. Figure No. 2. is a schematic of the conventional plant used in this study.

The conventional plant heating system is designed to serve a hydronic four-pipe $\theta^{5}$ thermal distribution system that supplies heat transfer fluid to a fan-coil space conditioning heat-exchanger. The fan-coil system was chosen as representative of the systems normally installed for large mult unit residential, hotel or institutional users. There is little or no impact on the distribution system or individual fan-coil units as the result of changing the thermal energy source (to a fuel cell).

\section{Space and Water Heating}

Thermal energy is supplied to the space heat system by a gas-fired boiler or fuel cell and to a separate potable water system through a heat exchanger. The normal space heating fluid supply temperature is about $80^{\circ} \mathrm{C}$. This is comparable to thermal energy delivery temperature of presently available fuel cells, $\left(40-80^{\circ} \mathrm{C}\right)$. The space heating and the domestic hot water are supplied by separate systems. The water normally used as the heat transfer fluid in a space heating system is heavily treated to prevent corrosion. These treatments are not potable.

\footnotetext{
${ }^{4}$ The configuration of the conventional systems defined in this report was based on information from energy users in the Southern California Area, and from design standards and recommendations from ASHRAE, GRI, DOE, SCAQMD, Southern California Edison, and The Southern California Gas Company.

${ }^{5}$ As illustrated in Figure No. 2, a four pipe system refers to the supply and return lines for the heat transfer fluid that provides heating and cooling to heat exchangers at the point-of-use.
} 


\section{Space Cooling}

As illustrated in Figure No. 2, smaller cinventional plant designs produce chilled water for space cooling with a vapor-cycle centrifugal chiller. Gas-fired boilers and electric driven centrifugal chillers were included in the conventional central utility plant because of their wide-spread use in commercial installations. The hydronic space conditioning system was selected because of it's ready adaptability between conventional gas fired-boilers and fuel cell supplied thermal energy. "Suitable applications (of fan coil systems) are hotels, motels, apartment buildings and office buildings. Fan-coil systems are used in a number of hospitals. $6^{n}$

Figure No. 2, Conventional Central Utility Plant

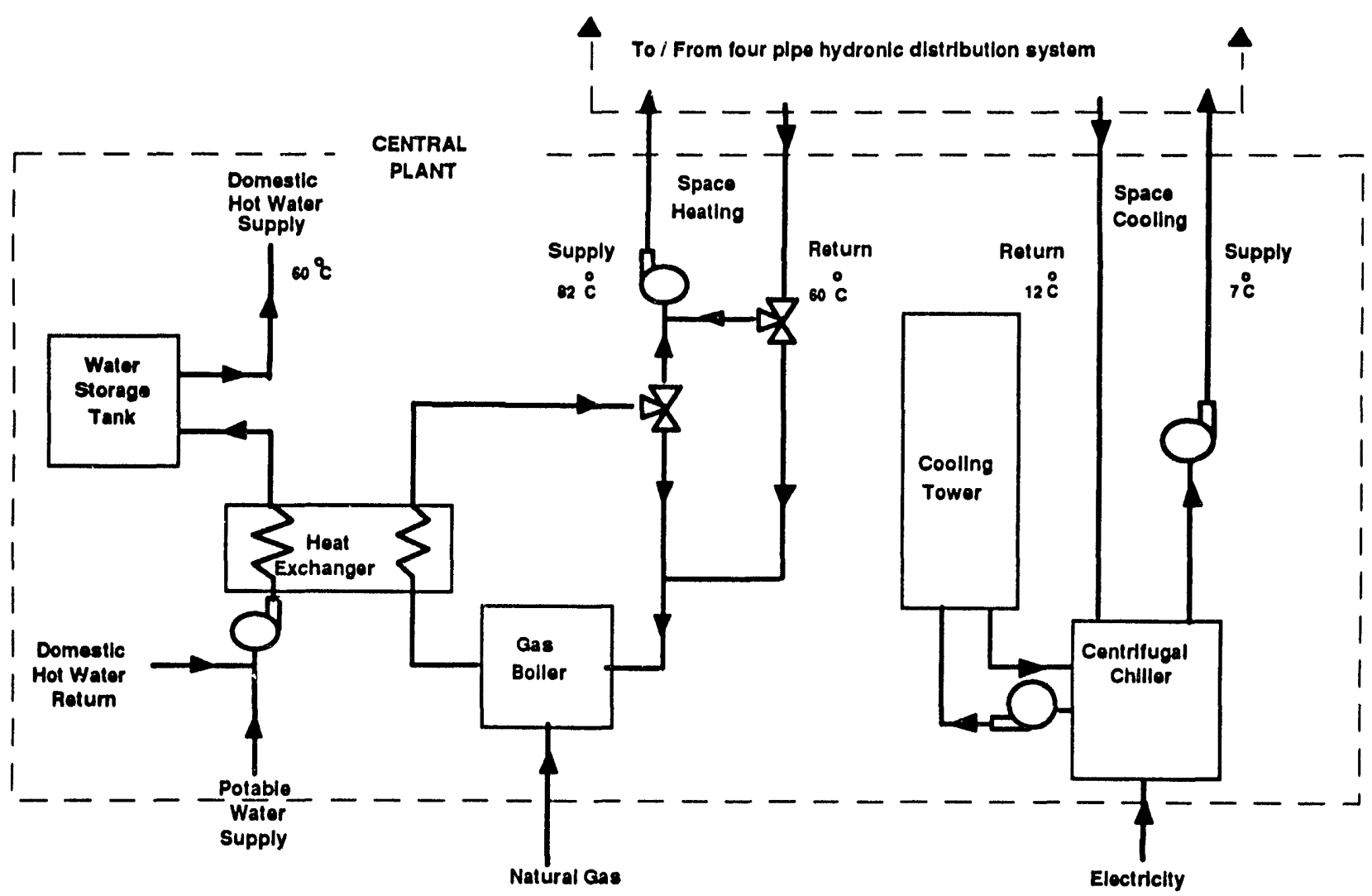

\section{Fuel Cell-Based Plant Design Features}

The design of a fuel cell-based central utility plant is similar to a conventional plant design. Both systems are designed to deliver hot and chilled water to a hydronic, four pipe thermal distribution system. Both designs also segregate the potable water system from the water used as the heat transfer fluid. This requires a secondary heat transfer loop. This loop is an essential feature of a multi purpose utility plant rather than an addition required by the fuel cell. 
Figure No. 3 is a schematic of the fuel cell based plant design used in this study. The difference between this and the conventional plant design are: 1.) the fuel cell 2.) a large hot water storage tank, the substitution of an absorption chiller for trie electric powered-centrifugal chiller and 4.) an additional heat transfer loop to supply hot water or steam to the chiller. The principle of operation and the basis for equipment selection is described in the following paragraphs.

\section{Fuel Cell}

There are several different fuel cell technologies 7 now in hardware development or entering the early stage of commercialization. The principle of operation is the same for each type of fuel cell. A natural or synthetic gaseous fuel comprised mainly of methane is reformed over a catalyst with high temperature steam to produce hydrogen and carbon monoxide. The carbon monoxide is further reacted with water to produce additional hydrogen and carbon dioxide. The hydrogen is reacted with oxygen from the air in an electrolyte to produce an electron flow, hot water or steam and carbon dioxide. The principle of operation of each type of cell is the same. They differ only in electrolyte material and operating conditions. The currently available cell uses a liquid phosphoric acid electrolyte and produces hot water at 71 to $100^{\circ} \mathrm{C}$. The next available technology will use a molten carbonate salts electrolyte. That cell will be followed in several years by a permeable, solid oxide electrolyte. The newer processes produce substantially higher temperatures than the phosphoric acid electrolyte cell. This enhances the utility of the thermal energy produced.Figure

No. 3, Fuel Cell-Based Central Utility Plant

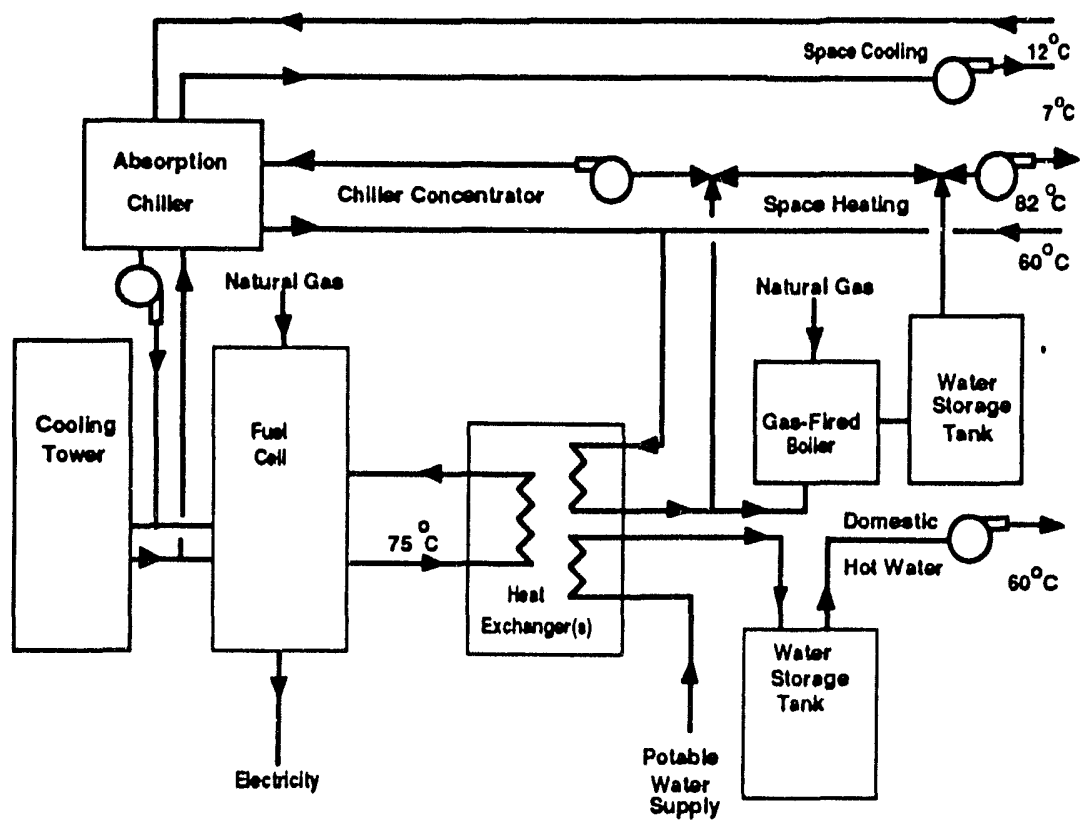

7There are three types of fuel cells being considered for stationary power generating applications. The fuel cell types are designated by the electrolyte that is used for the electrochemical reaction that produces electric power and hot water or steam. The phosphoric acid electrolyte cell was recently introduced to commercial markets by ONSI Corp. A fuel cell that uses molten carbonate salts as an electrolyte is in development by a consortium, MC.Power. The first pilot plant application of this technology is under construction in the PG\&E service area. The more advanced solid oxide electrolyte cell is being developed 


\section{Space Heating}

The fuel cell is used as a boiler preheater, as reflected in Figure No 3 . The boiler is sized to deliver all of the thermal energy required by the application, including that iormally supplied by the fuel cell. This redundancy is important in colder climates where there are health and safety issues associated with the loss of space heat (due to an unplanned outage of the fuel cell). The boiler is also used to raise the $75^{\circ} \mathrm{C}$ fuel cell exit temperature to the level required in the absorption chiller concentrator loop. In very large cooling applicaions (over 400 tons) the fuel cell output could be used as the first stage in a multi stage absorption chiller.

\section{Space Cooling}

The economic viability of the fuel cell is dependent upon productive use of the thermal energy produced by the power plant. The potential fuel cell owner should exploit the availability of the "free" thermal energy in the design of the central utility plant. The equipment in the analysis of the fuel cell-based central utility plant design includes absorption cooling for larger applications. A $200 \mathrm{~kW}$ phosphoric acid fuel cell produces $850,000 \mathrm{Btu} / \mathrm{hr}$ in the form of hot $\left(75^{\circ} \mathrm{C}\right)$ water. This will supply $70 \%$ of the energy required to power a 100 Ton absorption chiller. An equivalent electric driven centrifugal chiller to replace this cooling capacity requires $50 \mathrm{~kW}$. However, the capital cost ${ }^{8}$ of smaller absorption chillers is higher than centrifugal chiller ${ }^{9}$, yet absorption chillers smaller than 100 Tons are not manufactured. Utility plant applications, that are large enough to demand $200 \mathrm{~kW}$ or more, frequently require at least 100 Tons of refrigeration capacity. A tradeoff analysis was made to choose choice between absorption and electric driven centrifugal chillers.

Table No. 1 is a comparison of the net present value of capital and operating costs of electric powered and gas fired absorption chillers. The computation of operating costs assumed that the chillers were operated on a $28 \%$ duty-cycle. Absorption chilling is more economical than an electric driven, centrifugal chiller. This is true even if it is necessary to purchase the thermal energy at $\$ 3.00$ per million Btu to fire the unit. Recall that a fuel cell produces 425,000 Btu per $100 \mathrm{~kW}$ "hr of electricity produced. For the sample case the "free energy" amounts to 1.4 of the 2.5 million Btu per hour required. The present value of the 200 ton

\section{Table No. 1, Comparison of Absorption and Centrifugal Chillers}

\begin{tabular}{|c|c|c|c|c|c|c|c|c|}
\hline \multicolumn{9}{|c|}{ ABSORPTION } \\
\hline $\begin{array}{l}\text { Cooline } \\
\text { Tons }\end{array}$ & $\begin{array}{l}\text { Capacity } \\
\text { MMBtu/hı }\end{array}$ & $\begin{array}{l}\text { Capital } \\
\text { Cost }\end{array}$ & $\begin{array}{l}\text { Aux } \\
\text { Capital }\end{array}$ & $\begin{array}{l}\text { Power } \\
\mathrm{Kw} \text { "hr/yr }\end{array}$ & $\begin{array}{l}\text { Annual } \\
\text { Thermal }\end{array}$ & $\begin{array}{c}\text { Power } \\
\$ / y r\end{array}$ & $\begin{array}{c}\text { Thermal } \\
\text { Value, } S / Y^{\prime}\end{array}$ & $\begin{array}{l}\text { Present } \\
\text { Value }\end{array}$ \\
\hline 200 & 2.40 & $\$ 107,709$ & $\$ 14,400$ & 13346 & 10512 & $\$ 1,708$ & $\$ 25,162$ & $(\$ 491.977)$ \\
\hline \multicolumn{9}{|c|}{ CENTRIFUGAL } \\
\hline 200 & 2.40 & $\$ 122,303$ & $\$ 14,400$ & 292000 & N/A & $\$ 37,376$ & N/A & $(\$ 651,177)$ \\
\hline
\end{tabular}

by several firms in the United States and Japan under the sponsorship of commercial interests, the Department of Energy and public utilities.

${ }^{8}$ The Trane Company, Commercial Systems Group 
absorption chiller used if in the example case for this model is $25 \%$ less than the electric powered unit. Absorption chilling is the clear choice for large space cooling applications.

\section{Water Storage Tank}

The fuel cell-based central utility plant design includes two water storage tanks. The potable water system provides hot water for cooking and sanitation and a second tank acts as a "thermal accumulator" for the system. The accumulator is used to smooth thermal demand peaks in residential applications. In these applications there are large surges in thermal energy (hot water) demand for bathing and cooking early in the morning and lais in the evening. The tank should store the difference between the average and the peak thermal energy consumption. The average to peak ratio for residential applications is about 0.7 .

A tank to average the thermal demand for a hotel will hold about 2,000 callons and 1.7 million Btu. If all of the energy is recovered every day the present value of the energy savings is $\$ 25,000$ from a water tank investment of $\$ 18,000^{10}$. The accumulator also simplifies energy management and fuel cell controls.

9 R.S. Means Co. "Means Mechanical Cost Data" Construction Consultants and publishers, Kingston, MA ${ }^{10}$ See Note No. 9 


\section{Central Utility Plant Model Description}

The central utility plant model computes the capacity each plant element. The capacity for fuel cell production of electrical and thermal energy developed from user selected demand schedules and scaled to the appropriate load by peak demand. Thermal energy produced and natural gas consumed by the fuel cell are calculated from their relationship to electric power produced. The capacity of the ancillary equipment is also computed. Figure No. 4. is a schematic of the model logic. The titles of the model discussion sections are shown on the schematic in shadowed boxes to assist in establishing the relationship of the text to the model logic.

Figure No. 4, Central Utility Plant Model

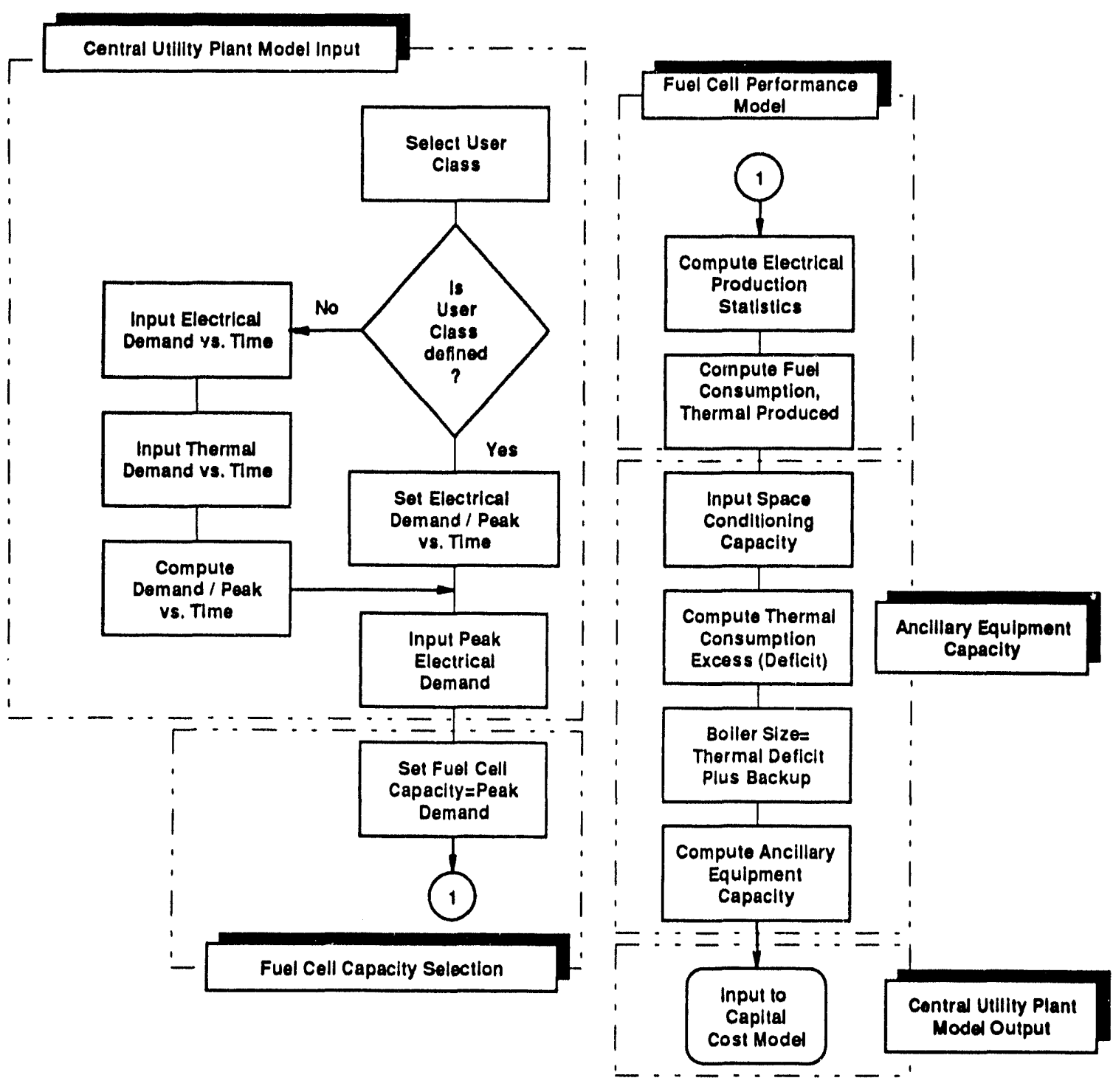




\section{Central Utllity Plant Model Input}

The model user specifies the energy consumption "user class" and the peak electrical load in kW. A class I user is characterized by residential use. This includes large multi unit residential buildings such as hotels, hospitals and prisons. The Class II users are large office buildings or retail stores and shopping malls. These applications are characterized by 12 to 16 hours of operation per day on five or seven days a week. Class III users are large industrial customers who consume energy at a relatively constant rate in threeshift operations, such as food processors and beverage bottlers. The model user specifies the Class by entering 1,2 or 3 on the model input sheet.

The model also provides for demand situations that may not fit the pre defined demand profiles. A Class IV user profile is defined in those cases. The Class IV user is not defined by the model. The user may input a set of 24 values for hourly electrical demand in $\mathrm{kW}$ and thermal demand in $1000 \mathrm{Btu}$ per hour. This enables the model user to combine demands from different sources to match to match the fuel cell capacity with a steady demand and maximize the production of thermal energy. The model computes the user demand schedule from the user specified input. Table No. 2 is a copy of the model input sheet. The required user input is entered on the shaded areas. Other parameters may be changed if desired.

Table No. 2, Central Utllity Plant Model input Sheei

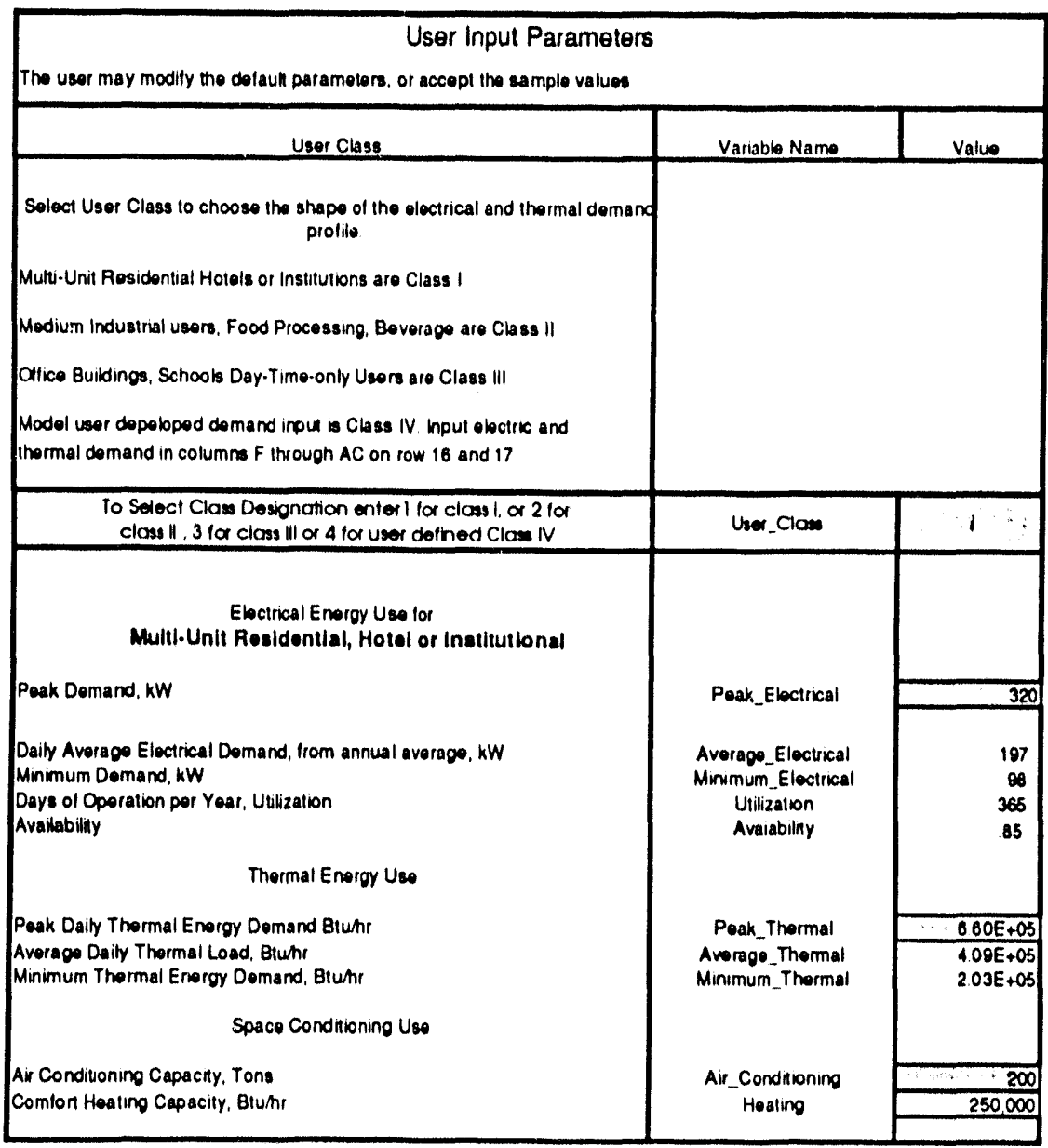


The user is also asked to specify the required space heating and cooling capacity. The model will assign hourly demand appropriate to the season of the year. The electrical and thermal demand profiles are estimated by the model from the data accumulated by the "Combined Use Energy Survey"1". The model will supply the number of days per week of operation and the number of heating days per year.

\section{Fuel Cell Capacity Selection}

The model sets the fuel cell capacity to satisfy the user specified peak electrical demand. The capacity best suited for an application depends upon the application demand profile, the cost of the alternative or replacement electrical power, the price that the owner will be able to recover from the sale of excess power and the capital and operating cost of the fuel cell. Figure No. 4. is a demand profile for a hypothetical Class I user, a large hotel that operates 24 hou's per day, seven days per week.

\section{Figure No. 5, Idealized Class I User Demand Curve}

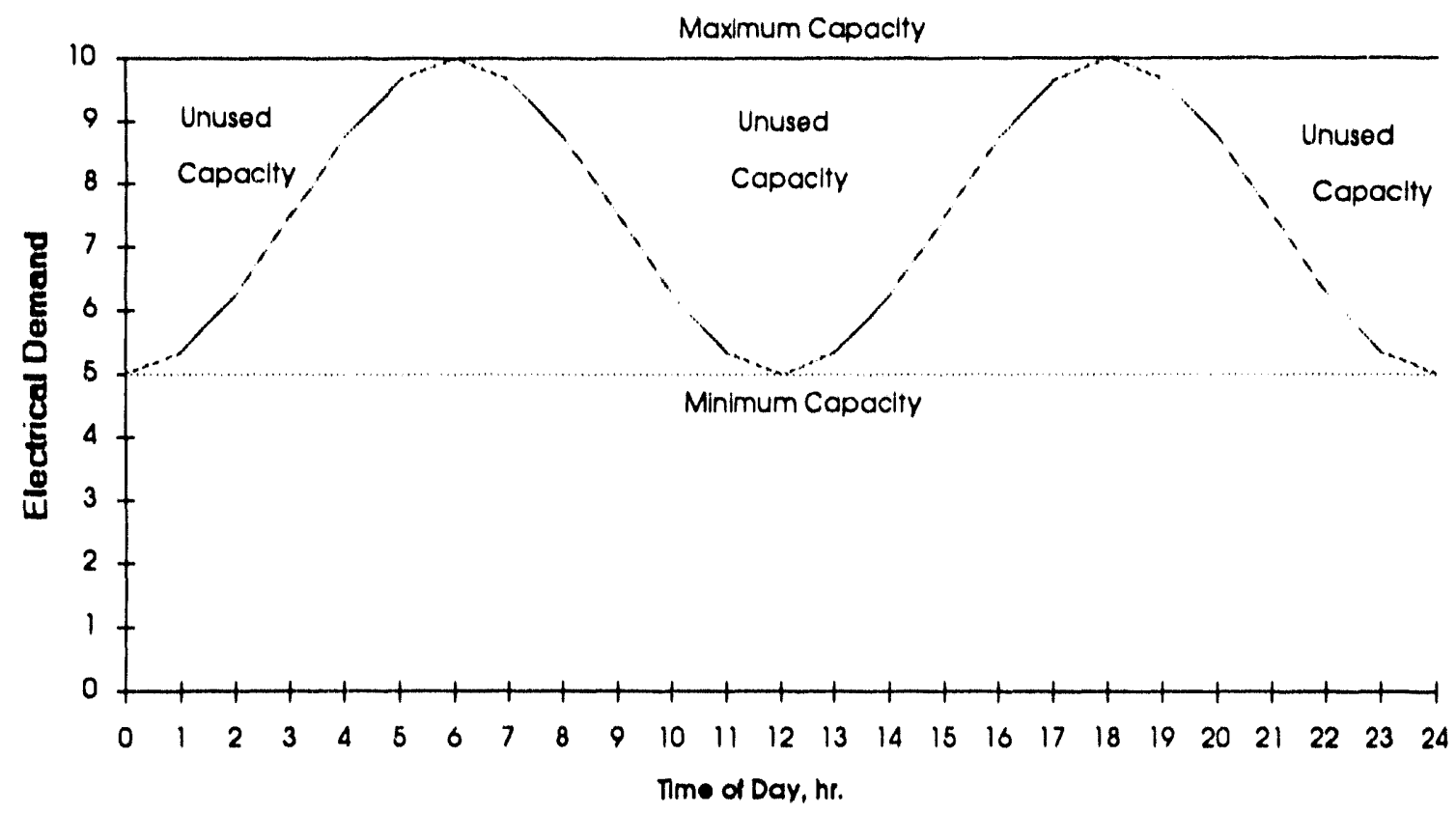

The process of selecting a fuel cell capacity is principally based upon the application's demand for electrical energy. Thermal energy is also important to the user and a significant element of the cost-ofownership. However, thermal energy utilization does not drive the sizing process. The economic replacement value of the thermal energy produced is only $11 \%$ of the total energy produced by the fuel cell and can be readily supplemented with an auxiliary boiler. Daily (or week-end) swings in thermal demand can be economically smoothed with a large hot water storage tank and need not be considered when the fuel cell operational policy is set. The central utility plant model compensates for thermal energy shorffalls by increasing boiler fuel gas consumption. Any excess thermal energy (usually during the summer airconditioning season) is rejected to the cooling tower.

11"Combined Use Energy Survey" prepared by Manes Associates, Inc. under contract No. DE.FC.MC29227 
The fuel cell output is reduced during the off-peak periods by modulating the gas supply. This demandmatching model was selected under the following assumptions.

1. All of the electrical energy requirements of the application may be met by purchasing the required power from the utility. No fuel cell installation is required. This is used as the basis for economic comparison of central utillty plant design options. Case 1. also illustrates the consequences of falling to provide the power required by the application.

2. The constant, minimum electrical demand of an application (Figure No. 4, Minimum Capacity line) can be met with a fuel cell, operating at design conditions. Additional power must be purchased to satisfy electric energy demand in exce. in fuel cell capacity or in the event of an unplanned outage. The scenario is economically valid only if the power purchase price is less the sum of the fuel cell capital and operating costs during the peak period.

3. The entire demand profile is met with a fuel cell, ( Figure No. 4, Maximum Capacity line) sized for the maximum electrical demand. The excess power, generated during off-peak periods is sold back to the utility. This scenario is important in utility service areas ${ }^{12}$ that need generating capacity and are pricing their buy-back rates accordingly.

4. The entire demand profile is met with a fuel cell, sized for the maximum electrical demand. There is no excess power generated. The fivel cell is operated to match demand by modulating fuel input. This option can prove attractive, considering current Southern California energy prices with fuel cell capital cost in the range of $\$ 1200$ to $\$ 2500$ per $\mathrm{kW}$. This translates into 5 to 25 mils per $\mathrm{kW}$ *hr depending upon investment recovery factors. As long as the fixed capital costs are a small fraction of the total cost of power production and the pea': demand is close to the mean, the case 4 option produces the lowest total cost for electrical energy. A corollary case can be developed by the user by combining the demand of several users ${ }^{13}$ to use the entire capacity of the fuel cell. This produces the lowest cost of electric power and ownership for all circumstances.

\section{Fuel Cell Performance Model}

The model computes the electrical power produced by the fuel cell by scaling the demand profile by the user input peak demand. The natural gas consumption and the thermal energy produced are computed as dependent variables of the electric power produced. The mathematical model for the computation is graphically represented in the following Figure No. 5. The curves are based upon empirical data taken from measured fuel cell performance. The fuel cell has good "turn-down" performance. The efficiency of the currently available model is close to the theoretical maximum efficiency at the design point and down to about $30 \%$ of the design point electrical energy production.

\footnotetext{
12Untortunately this is not true in Southern California. The CPUC approved buy-back rate, paid to indepencient power producers, is only 32 mils per $\mathrm{kW}$ in the sulnmer and 37 mils during the winter. The operating cost of a fuel cell is between 30 and 70 mils per $\mathrm{kW}$ "hr. Despite this severe economic disadvantage to operation during off-peak periods the choice can be preferable to purchasing on-peak (over-design capacity) energy at 141 mils per kW"hr.

${ }^{13}$ Current CPUC regulations do not permit sales to more than one customer and the utility in the service area if the energy is metered. The fuel cell owner can include the energy as part of another service (rent) if the power transmission lines do not cross public right-of-way. Provisions of The Energy Act of 1992 will eventually force modifications to these regulations. "Wheeling" electric power to other customers will be permitted just as gas utility transportation charges services are now "unbounded"" and priced separately from gas purchases.
} 
This characteristic is useful in low-demand operating situations wherein the operator can reduce electrical output and conserve fuel with no loss in energy conversion efficiency.

Figure No. 6, Fuel Cell performance Model

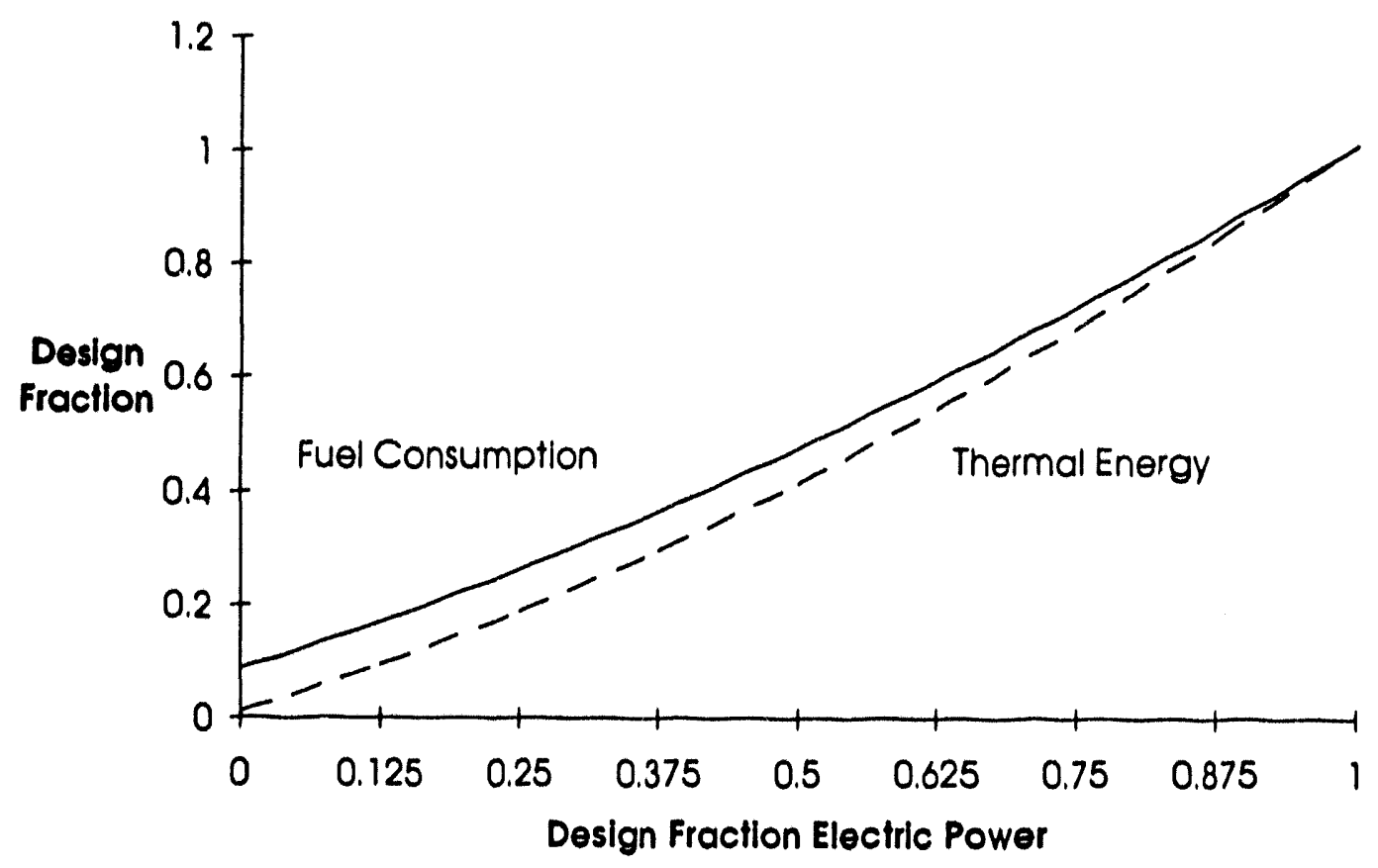

\section{Ancillary Equipment Capacity}

The capacity of the remaining elements of the central utility plant is computed from the thermal energy produced by the fuel cell and the user input air conditioning and comfort heating requirements.

\section{Auxiliary Boiler Model}

The model sizes the auxiliary boiler to produce the thermal demand of the application as a backup. If the additional capacity required for the absorption chiller is larger than the back-up requirement, the boiler is sized to meet the chiller requirements. The boiler efficiency is a user input that defaults to $90 \%$, consistent with the current state-of-the-art of fire-tube bollers.

\section{Thermal Accumulator (Water Storage tanks)}

The thermal demand of the typical class I user peaks sharply in the early morning and in the evening. The demand can be smoothed by a thermal accumulator that smoothes the thermal demand of the system. During the peak daylight hours thermal energy is supplied from the stored hot water. The excess thermal energy, available during off-peak mid-day and evening periods, is stored for use in the accumulator tank. 
The volumetric capacity of the tank is computed as the volume required to store the difference in energy between the daily average thermal demand and the peak demand. The energy is computed as the product of the fuel cell delta temperature and the weight of the water in the tank.

\section{Cooling Tower}

The cooling tower is sized to reject the thermal energy absorbed by the absorption chiller plus the energy transferred into the absorbers concentrator loop. The fuel cell installation also requires a back up method to reject the thermal energy produced in the event of fallure of the heat transfer equipment. Since the cooling tower capacity required by the chiller circuit is substantially larger than the thermal energy produced by the fuel cell, the tower need not be larger to provide backup.

\section{Central Utility Plant Model Output}

The results of the model calculations of fuel cell performance, ancillary equipment capacity and natural gas consumption are combined into the model output sheet. Table No. 3. is a sample output from the Central Utility Plant model that will be used in the cost-of-ownership analysis and for input to the operations model. Table No. 4 is an accumulation of the constant values that are used in the analysis. The user may modify any of these constant values as necessary to reflect their specific application or locale.

Table No. 3, Central Utility Plant Model Output

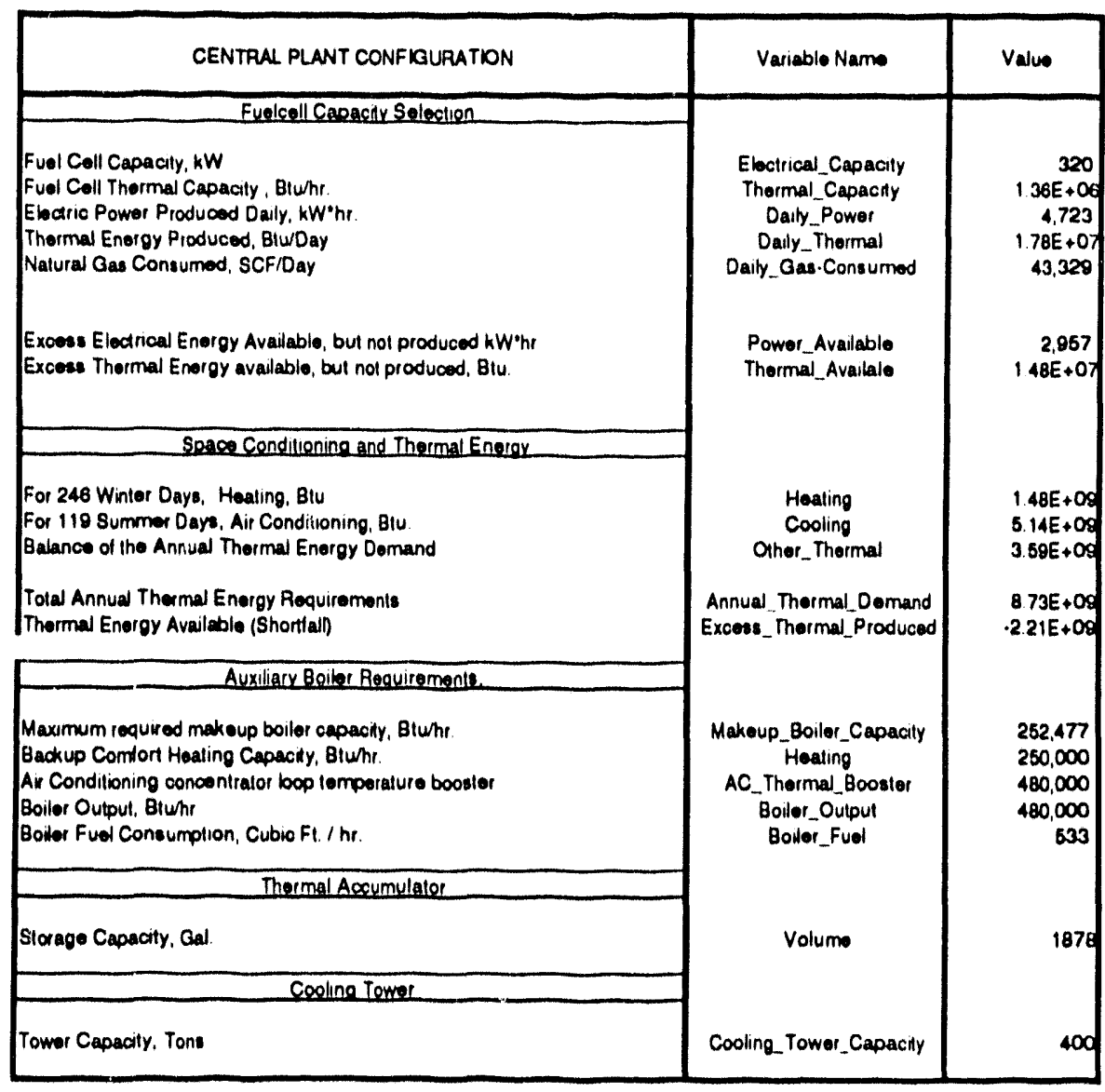


Table No. 4, Central Utility Plant Model Constants

\begin{tabular}{|c|c|c|}
\hline CENTRAL UTILTY PLANT MODEL CONSTANTS & Constant_Name & Valive \\
\hline 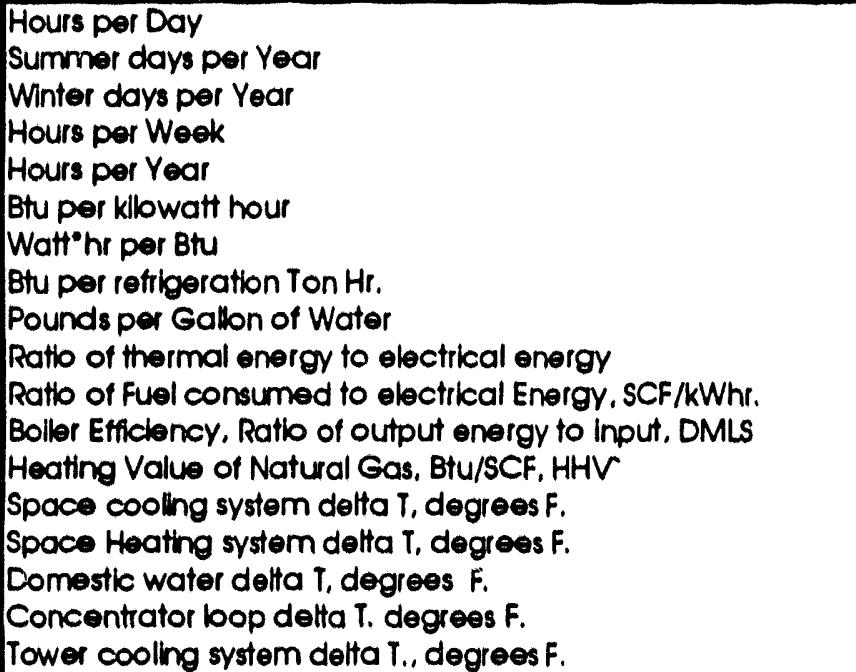 & $\begin{array}{c}\text { Day } \\
\text { Summer } \\
\text { Winter } \\
\text { Week } \\
\text { Year } \\
\text { Btu_per_kW_Hr } \\
\text { WattH__per_Btu } \\
\text { Btu_perTon_Hr } \\
\text { Lb_per_Gallon } \\
\text { Hrate } \\
\text { Gasrate } \\
\text { Boller_Efficiency } \\
\text { Heating_Value } \\
\text { Cooling_Delta_T } \\
\text { Heating_Delta T } \\
\text { Domestic_Delta_T } \\
\text { Concentrator_Delta_T } \\
\text { Tower_Delta_T }\end{array}$ & $\begin{array}{r}24 \\
119 \\
246 \\
168 \\
8760 \\
3413 \\
0.2929 \\
12000 \\
8.33 \\
4250 \\
9.5 \\
0.9 \\
1000 \\
9 \\
40 \\
70 \\
72 \\
13\end{array}$ \\
\hline
\end{tabular}




\section{BIBLIOGRAPHY}

1. ASHRAE, ASHRAE Handbook: Equipment 1988, Chapters 13, 23.

2. ASHRAE, ASHRAE Handbook: Systems 1984, Chapters 5, 13.

3. GRI, Comparative Market and Economic Analyses: Onsite Fuel Cells, Final Report Vol. I, Dec. 1980, GRI-79/0095.

4. GRI, Comparative Market and Economic Analyses: Onsite Fuel Cells, Final Report Vol. II. Appendices, Dec. 1980, GRI-79/0095.2.

5. GRI, 481 Prototypical Commercial Buildings for Twenty Urban Market Areas, Dec. 1990, GRI.90/0326

6. International Fuel Cells, The PC-25 Fuel Cell Power Plant, Aug. 1986.

7. S. Means Co. Inc., Means Facilities Cost Data 1993 Construction Consultants \& Publishers, Kingston, MA 1993

8. S. Means Co. Inc., Means Mechanical Cost Data 1992, Construction Consultants \& Publishers, Kingston, MA 1992.

9. Stamper \& Koral, Handbook of air-conditioning, Heating and Ventilating, Chapters 7.

10. GRI, Commercial Buildings Cogeneration Market: Characterization and Trends, April 1990 GRI.89/0246

11. GRI, 40-kW Onsite Fuel Cell Field Test Summary Utilities Activities Report - Final Report, July 1987, GRI-87/0205

13. The Trane Company, Commercial Systems Group Product Information Literature, Single Stage Absorption Cold Generator: 101 to 1660 Tons, La Crosse, WI, March 1989 
14. Manes Associates, Combined Use Energy Survey, Published under contract DE-FC92MC29227, as part of An Economic Feasibility Analysis of Distributed Electric Power Generation Based Upon the Natural Gas-Fired Fuel Cell, November 1992

15. Manes Associates, A Central Plant Utility Model, Published under contract DE-FC92-MC29227 as part of An Economic Feasibility Analysis of Distributed Electric Power Ganeration Based Upon the Natural Gas.Fired Fuel Cell, November 1992

16. Energy Information Administration, U.S. Department of Energy, Annual Energy Outlook 1993 DOE/EIA-0383 (93), January 1993 


\title{
GLOSSARY OF TERMS
}

\begin{abstract}
Absorption chiller
The absorption chiller is a refrigeration system that uses the evaporation and condensation of a lithium bromide salt and water solution to produce refrigeration. The evaporation is driven by thermal energy as steam or hot water. The temperature of the refrigerant (gas) is reduced by transfer to a wet cooling tower. The cool gas is returned to the point of refrigeration where the condensation absorbs the heat. The hat liquid is returned to the evaporator and the process is repeated. The system has been in commercial use for a number of years. It is marketed by Trane and Rheem.
\end{abstract}

\section{Centrifugal chiller}

The centrifugal chiller is a freon vapor-cycle refrigeration system that uses a mechanically driven centrifugal compressor. These systems are common in large industrial applications where the required system capacity is from 10 to 200 tons.

\section{Fan-coil heat exchanger}

The fan-coil heat exchanger is used on hydronic space conditioning systems. They are installed at the point-of-use provide heated or chilled air. Hot and cold fluid are supplied to a temperature controlled valve that admits the correct temperature fluid to the heat exchanger coil. The heat exchanger fan circulates room air across the heat exchanger coil.

\section{Hydronic}

A hydronic space conditioning system provides heating or cooling by circulating a heat transfer fluid (usually treated water) from a central heating or chilling source to the point of use.

\section{Potable}

A potable water source delivers water that is suitable for drinking.

\section{Turn-down performance}

Turn-down performance is the performance of a machine that is operating at less than rated capacity. It is generally stated as the ratio of the performance at reduced load to the performance at full or design load. The term is commonly used to express the performance or efficiency of turbines or electrical generators. 


\section{APPENDIX 1, TRADEOFF OF ABSORPTION VERSUS CENTRIFUGAL CHILLING}

This appendix is a comparison of the net present value of capital and operating costs of electric powered and gas fired absorption chillers over a range of sizes that are of interest of large industrial users. The computation of operating costs assumed that the chillers were operated on a $28 \%$ duty-cycle. Absorption chilling is more economical than an electric driven, centrifugal chiller. This is true even if it is necessary to purchase the thermal energy at $\$ 3.00$ per million Btu to fire the unit. Recall that a fuel cell produces 425,000 Btu per $100 \mathrm{~kW}$ "hr of electricity produced. For the "boxed" sample case the "free energy " amounts to 1.4 of the 2.5 million Btu per hour required. The present value of the 200 ton absorption chiller used if in the example case for this model is $25 \%$ less than the electric powered unit. Absorption chilling is the clear choice for large space cooling applications.

\section{ABSORPTION}

\begin{tabular}{ccccccccc}
$\begin{array}{c}\text { Cooling Capaclty Capltal } \\
\text { Tons MMBtu/hr } \\
\text { Cost }\end{array}$ & $\begin{array}{c}\text { Aux } \\
\text { Capltal }\end{array}$ & $\begin{array}{c}\text { Power } \\
\text { Kw"hr/yr }\end{array}$ & $\begin{array}{c}\text { Annual } \\
\text { Thermal }\end{array}$ & $\begin{array}{c}\text { Power } \\
\$ / y r\end{array}$ & $\begin{array}{c}\text { Thermal } \\
\text { Value, } \$ / \mathrm{yr}\end{array}$ & $\begin{array}{c}\text { Present } \\
\text { Value }\end{array}$ \\
25 & 0.30 & $\$ 24,694$ & $\$ 1,800$ & 3777 & 1314 & $\$ 483$ & $\$ 3,145$ & $(\$ 81,500)$ \\
50 & 0.60 & $\$ 40,347$ & $\$ 3,600$ & 5753 & 2628 & $\$ 736$ & $\$ 6,291$ & $(\$ 150,785)$ \\
75 & 0.90 & $\$ 53,770$ & $\$ 5,400$ & 7358 & 3942 & $\$ 942$ & $\$ 9,436$ & $(\$ 217,187)$ \\
100 & 1.20 & $\$ 65,922$ & $\$ 7,200$ & 8762 & 5256 & $\$ 1,122$ & $\$ 12,581$ & $(\$ 281,963)$ \\
150 & 1.80 & $\$ 87,853$ & $\$ 10,800$ & 11208 & 7884 & $\$ 1,435$ & $\$ 18,872$ & $(\$ 408,504)$ \\
\hline 200 & 2.40 & $\$ 107,709$ & $\$ 14,400$ & 13346 & 10512 & $\$ 1,708$ & $\$ 25,162$ & $(\$ 532,428)$ \\
\hline 250 & 3.00 & $\$ 126,152$ & $\$ 18,000$ & 15282 & 13140 & $\$ 1,956$ & $\$ 31,453$ & $(\$ 654,583)$ \\
400 & 4.80 & $\$ 175,984$ & $\$ 28,800$ & 20327 & 21024 & $\$ 2,602$ & $\$ 50,324$ & $(\$ 1,014,208)$ \\
500 & 6.00 & $\$ 206,117$ & $\$ 36,000$ & 23276 & 26280 & $\$ 2,979$ & $\$ 62,906$ & $(\$ 1,250,139)$ \\
700 & 8.40 & $\$ 261,587$ & $\$ 50,400$ & 28550 & 36792 & $\$ 3,654$ & $\$ 88,068$ & $(\$ 1,716,106)$ \\
800 & 9.60 & $\$ 287,536$ & $\$ 57,600$ & 30960 & 42048 & $\$ 3,963$ & $\$ 100,649$ & $(\$ 1,946,904)$
\end{tabular}

\section{CENTRIFUGAL}

\begin{tabular}{ccccccccc}
25 & 0.30 & $\$ 19,662$ & $\$ 1,800$ & 36500 & N/A & $\$ 4,672$ & N/A & $(\$ 85,771)$ \\
50 & 0.60 & $\$ 36,160$ & $\$ 3,600$ & 73000 & N/A & $\$ 9,344$ & N/A & $(\$ 168,378)$ \\
75 & 0.90 & $\$ 51,643$ & $\$ 5,400$ & 109500 & N/A & $\$ 14,016$ & N/A & $(\$ 249,971)$ \\
100 & 1.20 & $\$ 66,502$ & $\$ 7,200$ & 146000 & N/A & $\$ 18,688$ & N/A & $(\$ 330,939)$ \\
150 & 1.80 & $\$ 94,977$ & $\$ 10,800$ & 219000 & N/A & $\$ 28,032$ & N/A & $(\$ 491,632)$ \\
\hline 200 & 2.40 & $\$ 122,303$ & $\$ 14,400$ & 292000 & N/A & $\$ 37,376$ & N/A & $(\$ 651,177)$ \\
\hline 250 & 3.00 & $\$ 148,806$ & $\$ 18,000$ & 365000 & N/A & $\$ 46,720$ & N/A & $(\$ 809,899)$ \\
400 & 4.80 & $\$ 224,928$ & $\$ 28,800$ & 584000 & N/A & $\$ 74,752$ & N/A & $(\$ 1,282,676)$ \\
500 & 6.00 & $\$ 273,670$ & $\$ 36,000$ & 730000 & N/A & $\$ 93,440$ & N/A & $(\$ 1,595,856)$ \\
700 & 8.40 & $\$ 367,852$ & $\$ 50,400$ & 1022000 & N/A & $\$ 130,816$ & N/A & $(\$ 2,218,912)$ \\
800 & 9.60 & $\$ 413,665$ & $\$ 57,600$ & 1168000 & N/A & $\$ 149,504$ & N/A & $(\$ 2,529,162)$
\end{tabular}




\section{APPENDIX 2, CENTRAL UTILITY PLANT PERFORMANCE MODEL EQUATIONS}

FUEL CONSUMPTION AS A FUNCTION OF POWER OUTPUT

\begin{tabular}{|c|c|c|c|c|c|c|c|c|}
\hline Power, kW & & Inches & Fuel & Calc. & & & & \\
\hline$x$ & $x \wedge 2$ & Y & $\mathrm{SCFH}$ & SCFH & DMLS $X$ & $x \wedge 2$ & DMLS Y & $\begin{array}{l}\text { CALC } \\
\text { DMLSY }\end{array}$ \\
\hline 0 & 0 & 0.215 & 173.39 & 166.28 & 0.0000 & 0.0000 & 0.0903 & 0.086561 \\
\hline 25 & 625 & 0.405 & 326.61 & 326.34 & 0.1250 & 0.0156 & 0.1700 & 0.169884 \\
\hline 50 & 2500 & 0.62 & 500.00 & 504.05 & 0.2500 & 0.0625 & 0.2603 & 0.262394 \\
\hline 75 & 5625 & 0.85 & 685.48 & 699.41 & 0.3750 & 0.1406 & 0.3568 & 0.364091 \\
\hline 100 & 10000 & 1.125 & 907.26 & 912.41 & 0.5000 & 0.2500 & 0.4723 & 0.474975 \\
\hline 125 & 15625 & 1.425 & 1149.19 & 1143.06 & 0.6250 & 0.3906 & 0.5982 & 0.595045 \\
\hline 150 & 22500 & 1.735 & 1399.19 & 1391.36 & 0.7500 & 0.5625 & 0.7284 & 0.724303 \\
\hline 175 & 30625 & 2.082 & 1679.03 & 1657.31 & 0.8750 & 0.7656 & 0.8741 & 0.862747 \\
\hline 200 & 40000 & 2.382 & 1920.97 & 1940.90 & 1.0000 & 1.0000 & 1.0000 & 1.010378 \\
\hline
\end{tabular}

USEFUL THERMAL ENERGY AS A FUNCTION OF ELECTRIC LOAD

\begin{tabular}{|c|c|c|c|c|c|c|c|c|}
\hline$, \mathrm{X}, \mathrm{KW}$ & $x \wedge 2$ & Y.in. & $\begin{array}{c}\text { Y. } \\
\text { Byu/hr }\end{array}$ & YCalc. & $\begin{array}{c}X . \\
\text { DMLS }\end{array}$ & $x \wedge 2$ & $\begin{array}{c}Y . \\
\text { DMLS }\end{array}$ & $\begin{array}{l}\text { Calc Y } \\
\text { DMLS }\end{array}$ \\
\hline 0 & 0 & 0.049 & 14010 & 9437 & 0.0000 & 0.0000 & 0.0169 & 0.011362 \\
\hline 25 & 625 & 0.26 & 74339 & 78137 & 0.1250 & 0.0156 & 0.0895 & 0.094074 \\
\hline 50 & 2500 & 0.545 & 155826 & 156861 & 0.2500 & 0.0625 & 0.1876 & 0.188854 \\
\hline 75 & 5625 & 0.855 & 244460 & 245609 & 0.3750 & 0.1406 & 0.2943 & 0.295703 \\
\hline 100 & 10000 & 1.193 & 341101 & 344381 & 0.5000 & 0.2500 & 0.4107 & 0.41462 \\
\hline 125 & 15625 & 1.575 & 450322 & 453176 & 0.6250 & 0.3906 & 0.5422 & 0.545606 \\
\hline 150 & 22500 & 2.025 & 578985 & 571996 & 0.7500 & 0.5625 & 0.6971 & 0.688659 \\
\hline 175 & 30625 & 2.485 & 710508 & 700839 & 0.8750 & 0.7656 & 0.8554 & 0.843781 \\
\hline 200 & 40000 & 2.905 & 830593 & 839706 & 1.0000 & 1.0000 & 1.0000 & 1.010972 \\
\hline
\end{tabular}

Calculated coefficients of thermal energy

$A X^{2}$

$\mathrm{BX}$

C

$\begin{array}{lll}0.3862 & 0.6134 & 0.0114\end{array}$

0.0301010 .0312840 .006709

$0.9995690 .008254 \quad \# \mathrm{~N} / \mathrm{A}$
Calculated coefficients of fuel consumption

$$
\begin{array}{lll}
A X^{2} & B X \quad C
\end{array}
$$

$\begin{array}{lll}0.2940 & 0.6298 & 0.0866\end{array}$

$\begin{array}{llll}0.027463 & 0.028543 & 0.006121\end{array}$

$0.9995780 .007531 \quad \# \mathrm{~N} / \mathrm{A}$ 


\section{APPENDIX 3, MODEL EQUATIONS}

\section{Select User Class}

Choose from among three pre defined user classes and set the model electrical and thermal demand equal to the selected class.

User_Class $=$ Class $(i)\left(\begin{array}{l}i=1 \\ i=3\end{array}\right)$

Electric_Demand $=$ Class $(i)$ Electric $\left[\begin{array}{l}t=1 \\ t=24\end{array}\right)$

Thermal_Demand $=$ Class $(i)$ Thermal $\left[\begin{array}{l}t=1 \\ t=24\end{array}\right)$

2. In applications where the demand profile does not match the predetermined "user classes" the model user can input the electrical demand and the thermal demand as 24 data pair in $\mathrm{kW}$ and thousands of Btu per hour. The user chooses class $=4$ and is presented with a data input screen. The program converts the demand data into a demand profile as a ratio of demand / peak demand. The class 4 profile is then treated the same as class 1,2 or 3 .

\section{Electric_Capacity $\equiv$ Max $($ Electric_Demand $)$}

2. For all other cases, set the fuel cell capacity equal to user input peak electrical demand

Electric_Capacity $\equiv$ Peak_Electrical

3. Compute daily fuel cell electrical production

Daily_Power $=$ Peak_Electrical $\times \sum_{t=1}^{24}[$ Electric_Demand $(t)]$

4. The natural gas consumption of the fuel cell as a fraction of the gas consumption at the design capacity is computed from as a quadratic function of the form $Y=a X^{2}+b X+c$. The independent variable is the ratio of the electric demand to the peak demand. The coefficients of $X, a_{8}, b_{8}$ and $\mathbf{c}_{8}$ were developed by multiple linear regression as described in Appendix 1 , from empirical data was taken from reference 6 . The fraction of design point gas consumption is converted to a dimensional value of standard cubic feet per hour by the constant Gasrate, SCFH / $\mathrm{kW}$.

Daily_GasConsumed $=$ Peak_Electrical $\times$ Gasrate $\times$

$\sum_{t=1}^{24}\left[a_{g} \times(\text { Electric_Demand }(t))^{2}+b_{g} \times(\right.$ Electric_Demand $\left.(t))+c_{g}\right]$ 
5. Equations for the daily production of thermal energy are similar to those for gas consumption. They differ only by the coefficients for the quadratic expression $a_{h}, b_{h}$ and $c_{h}$ and the ratio of the production of thermal energy to the production of electrical energy, Hrate. Daily thermal production is expressed in Btu per day

Daily_Thermal $=$ Peak_Electrical $\times$ Hrate $\times$
$\sum_{t=1}^{24}\left[a_{h} \times(\text { Electric_Demand }(t))^{2}+b_{h} \times(\right.$ Electric_Demand $\left.(t))+c_{h}\right]$

6. The daily gas consumption and thermal energy produced are convarted into annual rates by multiplying the daily rate times the summer days plus the daily rate times the winter days. The distinction between winter and summer is maintained to apply the appropriate gas purchase and electric power sales rates in the Operations model. The units of power produced is $\mathrm{kW} \mathrm{hr}$. Gas consumed is expressed in SCF

$W$ int er_Thermal_Produced $=$ Daily_Thermal $\times W$ inter_days

Summer_Thermal_Produced $=$ Daily_Thermal $\times$ Summer_Days

Annual_Thermal_Produced $=$ Summer_Thermal_Produced $+W$ int er_Thermal_Produced

$W$ int $e r_{\text {_Cas_Consumed }}=$ Daily_Gas_Consumed $\times W$ int $e r_{-}$Days

Summer_Gas_Consumed $=$ Daily_Gas_Consumed $\times$ Stummer_Days

Annual_Gas_Consumed $=W$ int $e r_{-}$Cas_Consumed + Summer_Cas_Consumed

7. Compute the heating and air conditioning thermal demand. The thermal energy required for heating is computed from the input space conditioning capacity, assumed duty cycle and the number of winter days. The assumed duty cycle is the dimensionless ratio of hours of operation at full capacity to the number of hours per day. The output is in Btu per year.

The air conditioning thermal energy requirement is computed from the input capacity, Air_Conditioning in tons, converted to Btu's times the assumed duty cycle times the number of cooling days in the summer divided by the coefficient of performance of the absorption chiller, COP. The output is in Btu per year.

Heating $=$ Space_Heat $\times 12 \mathrm{hr} /$ Day $\times W$ int er

Cooling $=$ Air_Conditioning $\times$ Blu_perTon_Hr $\times 12 /$ Day $\times$ Summer $/ C O P$

8. Compute the thermal energy production excess (deficit) to size the backup boiler and compute the boiler fuel requirements. The boiler is sized for the larger of comfort heating backup or air conditioning chiller input temperature booster.

Excess_Themal_Produced $=$

Annual_Thermal_Produced-(Annual_Heating + Annual_Cooling + Peak_Thermal $\left.\times \sum_{1}^{365} T h e r n a a l \_D e m a n d\right)$ 
Boiler_Output $=i f\left(\right.$ Excess_Thermal_Produced $>0$, Max (Heating, $A C_{-}$Thermal_Booster $)$,

Max(Heating, AC_Thermal_Booster,Excess_Thermal_Produced / Year))

Boiler_Fuel $=$ Boiler_Output_I(Heating_Value ${ }^{*}$ Boiler_Efficiency)

Where the boiler output is expressed in Btu per hour and the boiler fuel required is SCFH.

9. Compute the required storage capacity of the thermal accumulator tank

Mean_Thermal_Demand $=$ Peak_Thermal $\times \sum_{1}^{365}$ Thermal_Demand $) / 24$

Volume $=\left[\Sigma_{1}^{24}\right.$ if $\left\{\left(\right.\right.$ Peak_Thermal $\times \sum_{1}^{365}$ Thermal_Demand $\left.)\right)-$ Mean_Thermal_Demand $>0$,

(Peak_Thermal $\times \sum_{1}^{24}$ Thermal_Demand)) -Mean_Thermal_Demand,0)\} $] /($ Delta_T*|b_per_gallon)

Where Delta_T is the increase in the stored water temperature from room temperature to fuel cell output temperature. Volume is expressed in gallons.

10. Compute the cooling tower capacity. Fuel cell cooling is required in the event of failure of the heat transfer equipment. The absorption cooling equipment must have wet tower cooling to reject the heat removed from the application plus the thermal energy added to drive the process. It is assumed that only the larger demand will be designed for. Space cooling would be cut back to tower capacity in the event of a failure.

Cooling_Tower_Capacity $=$

[Max(Air_Conditioning* $(1+C O P))$, Hrate*Peak_Electricall Btu_perTon_hr]

Where cooling tower capacity is expresses in refrigeration tons per $\mathrm{hr}$. 

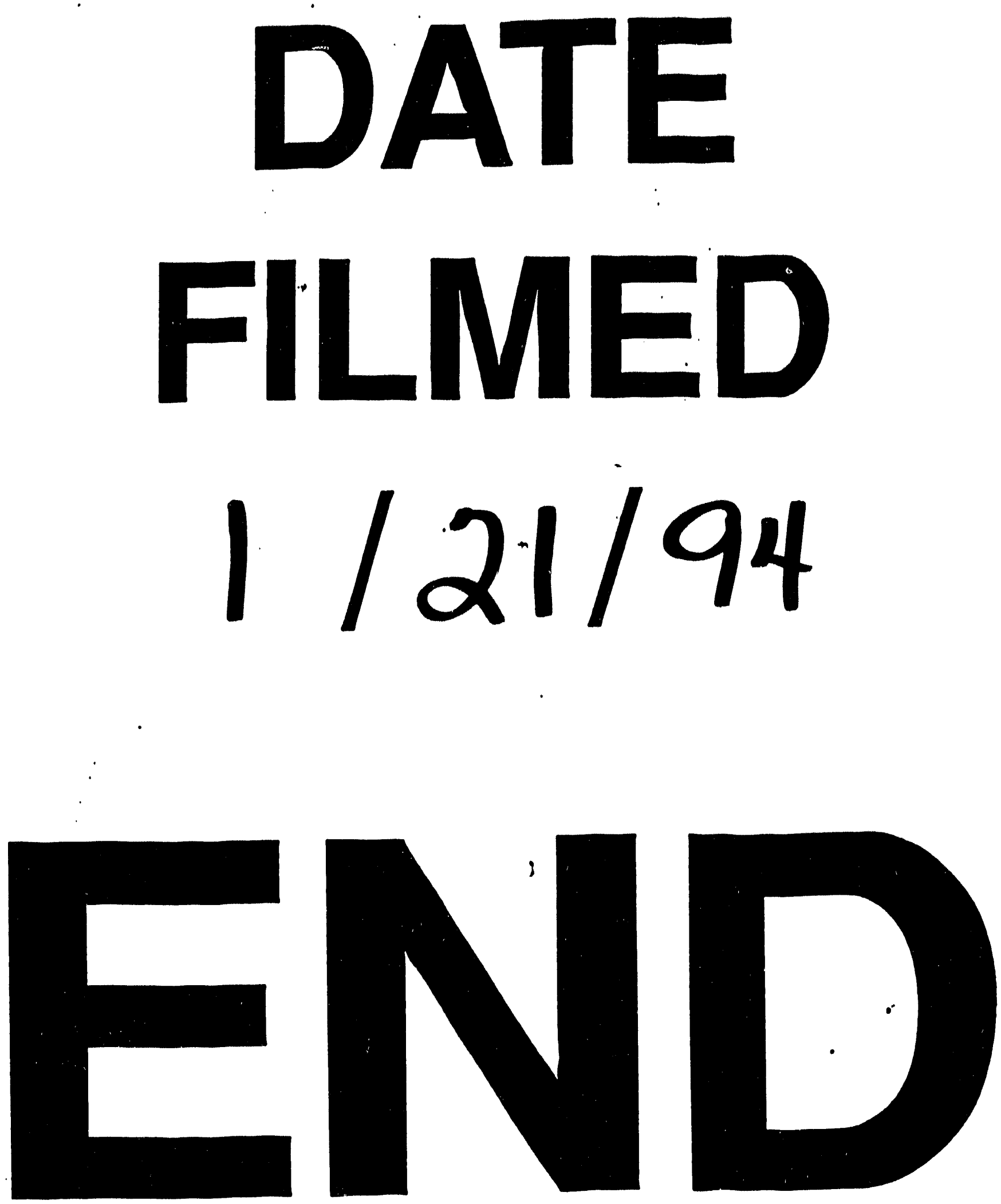
